Article

\title{
Primary Study for the Therapeutic Dose and Time Window of Picroside II in Treating Cerebral Ischemic Injury in Rats
}

\author{
Haitao Pei ${ }^{1}$, Xi Su ${ }^{1}$, Li Zhao ${ }^{2}$, Hongyun Li ${ }^{1}$, Yunliang Guo ${ }^{2 *}$, Menizeng Zhang ${ }^{3}$ and Hui Xin ${ }^{4}$ \\ 1 Department of Emergency Neurology, Affiliated Hospital of Qingdao University Medical College, \\ Qingdao 266003, China; E-Mails: peihtao@163.com (H.P.); hellosuxi@163.com (X.S.); \\ honyunli@gmail.com (H.L.) \\ 2 Institute of Integrative Medicine, Qingdao University Medical College, Qingdao 266003, China; \\ E-Mail: 675078982@qq.com \\ 3 Department of Neurology, Affiliated Hospital of Qingdao University Medical College, \\ Qingdao 266003, China; E-Mail: zmzcmd@yahoo.com.cn \\ 4 Department of Cardiology, Affiliated Hospital of Qingdao University Medical College, \\ Qingdao 266003, China; E-Mail: xhqy2002@163.com \\ * Author to whom correspondence should be addressed; E-Mail: guoqdsd@yahoo.com.cn; \\ Tel.: +86-0532-829-115-23; Fax: +86-0532-829-118-40.
}

Received: 30 December 2011; in revised from: 15 February 2012 / Accepted: 16 February 2012 / Published: 23 February 2012

\begin{abstract}
The aim of this study was to explore the optimal therapeutic dose and time window of picroside II for treating cerebral ischemic injury in rats according to the orthogonal test. The middle cerebral artery occlusion (MCAO) models were established by intraluminally inserting a thread into middle cerebral artery (MCA) from left external carotid artery (ECA). The successful rat models were randomly divided into 16 groups according to the orthogonal layout of $\left[L_{16}\left(4^{5}\right)\right]$ and treated by injecting picroside II intraperitoneally with different doses at various times. The neurological behavioral function was evaluated by Bederson's test and the cerebral infarction volume was measured by tetrazolium chloride (TTC) staining. The expressions of neuron specific enolase (NSE) and neuroglial mark-protein S-100 were determined by immunohistochemisty assay. The results indicated that the optimal compositions of the therapeutic dose and time window of picroside II in treating cerebral ischemic injury were ischemia $1.5 \mathrm{~h}$ with $20 \mathrm{mg} / \mathrm{kg}$ body weight according to Bederson's test, $1.0 \mathrm{~h}$ with $20 \mathrm{mg} / \mathrm{kg}$ body weight according to cerebral infarction volume, $1.5 \mathrm{~h}$ with $20 \mathrm{mg} / \mathrm{kg}$ body weight according to the expressions of NSE and S-100 respectively. Based on the principle of the minimization of
\end{abstract}


medication dose and maximization of therapeutic time window, the optimal composition of the therapeutic dose and time window of picroside II in treating cerebral ischemic injury should be achieved by injecting picroside II intraperitoneally with $20 \mathrm{mg} / \mathrm{kg}$ body weight at ischemia $1.5 \mathrm{~h}$.

Keywords: picroside II; cerebral ischemia; therapeutic dose; time window; NSE; S-100; rats

\section{Introduction}

Cerebral ischemic reperfusion injury is a pathological process resulting from many factors, such as excitatory amino acids releasing, oxidative stress, calcium ion overloading, inflammatory reaction, apoptosis, etc. [1-3]. Neuron-specific enolase and neuroglial mark-protein S-100 can reflect the degree of cerebral injury [4-6]. The former study of cell culture proved that pcroside II could lessen the injury to $\mathrm{PC} 12$ induced by $\mathrm{H}_{2} \mathrm{O}_{2}$ and raise the cell survival rate [7-12]. Some animal experiments proved that picroside II could inhibit apoptosis and the expression of related inflammatory factors in ischemic penumbra after ischemic reperfusion injury [13-15]. The authors' former experiments indicated that picroside II could reduce the degradation of the substrate, poly ADP-ribose polymerase (PARP) with catalytic activity, by inhibiting the expression toll-like receptor 4 (TLR4), nuclear transcription factor $\kappa \mathrm{B}$ (NFkB), tumor necrotic factor $\alpha(\mathrm{TNF} \alpha)$ and Capase-3, and make PARP to utilize the remanent energy in the cells of ischemic penumbra to repair the nerve cells which have the reversibility of refreshing, so that to inhibit the ischemic injury leading to the apoptosis [16-23]. However, in these experiments, the rats were treated by injecting picroside II with a simple dose $(20 \mathrm{mg} / \mathrm{kg})$ at a simple time after ischemia $(2 \mathrm{~h})$ from tail vein. In this study, the authors aimed to explore the optimal therapeutic dose and time window of picroside II injecting intraperitoneally in cerebral ischemic injury in rats according to the design principle of orthogonal test.

\section{Results and Discussion}

\subsection{Neurobehavioral Deficit Score}

After treated by picroside II, each rat showed behavioral defect at different degree. By the analysis of software of SPSS (set $\alpha=0.05$ ), the probability of significant interaction of independent variable was $0.46>0.05$ (Table 1), and there was no interaction between administering drug time and administering drug dose. From the result of analysis of variance, the significant probability of each independent variable was $P=0.02<0.05$. Therefore, medication time and dose have significant influence on recovery of neurological function. All data are analyzed by the statistical mean of two-way ANOVA (analysis of variance) and LSD (least significant difference) value, the analytic results showed that there was no significant differences between administering drug at ischemia $1 \mathrm{~h}$ (A1) and $1.5 \mathrm{~h}$ (A2), and between administering drug at ischemia $2 \mathrm{~h}$ (A3) and $2.5 \mathrm{~h}$ (A4), $P>0.05$. There was no significant deviation between administering drug doses of $5 \mathrm{mg} / \mathrm{kg}$ (B1) and $10 \mathrm{mg} / \mathrm{kg}$ (B2) and between administering drug doses of $20 \mathrm{mg} / \mathrm{kg}$ (B3) and $40 \mathrm{mg} / \mathrm{kg}$ (B4), $P>0.05$. In addition, there was a significant differences between each other for the rest groups, $P<0.05$, so that the better 
composition of the therapeutic dose and time window of picroside II were A1B3, A1B4, A2B3, A2B4. Considering the principles of medication dose minimization and therapeutic time maximization, it is presumed that $\mathrm{A} 2 \mathrm{~B} 3$ is the best composition, namely the best therapeutic time window and the best therapeutic dose of picroside II is ischemia $1.5 \mathrm{~h}$ with $20 \mathrm{mg} / \mathrm{kg}$ body.

Table 1. Analysis of variance about neurological function defect.

\begin{tabular}{cccccc}
\hline Variation source & SS & df & MS & $\boldsymbol{F}$ & $\boldsymbol{P}$ \\
\hline Time & 3.187 & 3 & 1.06 & 17 & 0.02 \\
Dose & 3.187 & 3 & 1.06 & 17 & 0.02 \\
Time*Dose & 0.188 & 3 & 0.63 & 1 & 0.45 \\
\hline Error & 0.375 & 6 & 0.63 & & \\
\hline
\end{tabular}

The significant probability of independent variable time was $P=0.02<0.05$; the significant probability of independent variable dose was $P=0.02<0.05$; the significant probability of independent variable interaction was $P=0.45>0.05$.

\subsection{Volume of Cerebral Infarction}

After treated by picroside II, all rats showed an infarction volume at different degree in the area supplied by middle cerebral artery with TTC staining. According to the analysis with software of SPSS (set $\alpha=0.05$ ), the significant probability of the interaction of independent variables is $0.23>0.05$, so there is no interaction between medication time and therapeutic dose (Tables 2 and 3). The result of ANOVA showed that the significance probability of every independent variable was $P<0.01$, which indicated the medication time and therapeutics dose of picroside II influenced on cerebral infarction volume significantly. All data are analyzed by the statistical mean of two-way ANOVA and LSD value. It is concluded that there was significant deviation between each other of medication time $(P<0.05)$, no significant deviation between therapeutic dose $20 \mathrm{mg} / \mathrm{kg}$ (B3) and $40 \mathrm{mg} / \mathrm{kg}$ (B4) ( $P>0.05)$, and there was a significant deviation between the rest combination, $P<0.05$. Therefore, the better combination of medication time and therapeutic dose were A1B3 or A1B4. According to the principles of the minimization of medication dose and maximization of therapeutic time, it is presumed that A1B3 is the best composition group, i.e., the best therapeutic time window and the best therapeutic dose of picroside II is ischemia $1 \mathrm{~h}$ with $20 \mathrm{mg} / \mathrm{kg}$ body.

Table 2. The infarction volume of tetrazolium chloride (TTC) staining.

\begin{tabular}{lcccc}
\hline Drug Dose & Ischemia 1.0 h & Ischemia 1.5 h & Ischemia 2.0 h & Ischemia 2.5 h \\
\hline $5 \mathrm{mg} / \mathrm{kg}$ & 69.05 & 73.00 & 73.40 & 75.50 \\
$10 \mathrm{mg} / \mathrm{kg}$ & 66.20 & 71.50 & 72.10 & 74.30 \\
$20 \mathrm{mg} / \mathrm{kg}$ & 64.90 & 69.30 & 71.60 & 73.90 \\
$40 \mathrm{mg} / \mathrm{kg}$ & 64.50 & 68.90 & 70.80 & 72.00 \\
\hline
\end{tabular}


Table 3. ANOVA of cerebral infraction volume.

\begin{tabular}{cccccc}
\hline Variation source & SS & df & MS & $\boldsymbol{F}$ & $\boldsymbol{P}$ \\
\hline Time & 130.46 & 3 & 43.49 & 150.30 & 0.00 \\
Dose & 30.32 & 3 & 10.11 & 34.93 & 0.00 \\
Time*Dose & 1.67 & 3 & 0.56 & 1.92 & 0.23 \\
\hline Error & 1.74 & 6 & 0.29 & & \\
\hline
\end{tabular}

The significant probability of independent variable time was $P=0.00<0.05$; the significant probability of independent variable dose was $P=0.00<0.05$; the significant probability of independent variable interaction was $P=0.23>0.05$.

\subsection{Expression of NSE Protein}

The immunohistochemisty staining shows that NSE in brain tissue expressed at different degrees, and mainly in cytoplasm with yellow or brown colors. The significance probability of the interaction of independent variables (the number of positive cells) is $0.78>0.05$, so there is no interaction between medication time and therapeutics dose (Tables 4 and 5). The result of ANOVA showed that the significance probability of every independent variable is less than 0.01 , which proved that medication time and therapeutic dose of picroside II could significantly influence the expression of NSE. All data are analyzed by the statistical mean of two-way ANOVA and LSD value, it is concluded that there was a significant deviation of NSE expression between each medication time $(P<0.05)$, while no significant deviation between $20 \mathrm{mg} / \mathrm{kg}$ (B3) and $40 \mathrm{mg} / \mathrm{kg}(\mathrm{B} 4)(P>0.05)$, but there was significant deviation between the rest therapeutic dose combination $(P<0.05)$. So the better combination of medication time and therapeutics dose is A1B3 or A1B4. Considering the minimization of medication dose and maximization of therapeutic time, it is presumed that A1B3 is the best combination, namely the best therapeutic time window and the best therapeutic dose of picroside II is ischemia $1.0 \mathrm{~h}$ with $20 \mathrm{mg} / \mathrm{kg}$.

Table 4. The expression positive cells of neuron specific enolase (NSE).

\begin{tabular}{lcccc}
\hline Drug Dose & Ischemia 1.0 h & Ischemia 1.5 h & Ischemia 2.0 h & Ischemia 2.5 h \\
\hline $5 \mathrm{mg} / \mathrm{kg}$ & 36.20 & 38.33 & 39.90 & 41.00 \\
$10 \mathrm{mg} / \mathrm{kg}$ & 35.00 & 36.90 & 37.55 & 38.00 \\
$20 \mathrm{mg} / \mathrm{kg}$ & 34.33 & 35.55 & 36.80 & 37.60 \\
$40 \mathrm{mg} / \mathrm{kg}$ & 34.20 & 35.60 & 36.20 & 37.20 \\
\hline
\end{tabular}

Table 5. ANOVA of positive cells of NSE.

\begin{tabular}{cccccc}
\hline Variation source & SS & df & MS & $\boldsymbol{F}$ & $\boldsymbol{P}$ \\
\hline Time & 27.497 & 3 & 9.17 & 39.39 & 0.00 \\
Dose & 22.928 & 3 & 7.64 & 32.85 & 0.00 \\
Time*Dose & 0.253 & 3 & 0.08 & 0.36 & 0.78 \\
\hline Error & 1.649 & 6 & 0.23 & & \\
\hline
\end{tabular}

The significant probability of independent variable time was $P=0.00<0.05$; the significant probability of independent variable dose was $P=0.00<0.05$; the significant probability of independent variable interaction was $P=0.78>0.05$. 


\subsection{Expression of S-100 Protein}

The immunohistochemial stain shows the expression of S-100 in brain tissue was at different degree and mainly in cytoplasm. The significance probability of the interaction of independent variables (the number of positive cells) is $0.35>0.05$, so there is no interaction between medication time and therapeutic dose (Tables 6 and 7). The result of ANOVA showed that the significance probability of every independent variable is smaller than 0.01, which suggested that the medication time and therapeutic dose of picroside II could significantly influence on S-100 expression. All data are analyzed by the statistical mean of two-way ANOVA and LSD value. It is concluded that there was no significant deviation of S-100 expression between ischemia $1 \mathrm{~h}$ (A1) and ischemia $1.5 \mathrm{~h}$ (A2), also ischemia $1.5 \mathrm{~h}(\mathrm{~A} 2)$ and $2 \mathrm{~h}(\mathrm{~A} 3)(P>0.05)$, while there was a significant deviation between the rest combination $(P<0.05)$. Although no significant deviation between therapeutic dose $5 \mathrm{mg} / \mathrm{kg}(\mathrm{B} 1)$ and $10 \mathrm{mg} / \mathrm{kg}(\mathrm{B} 2)$, or $20 \mathrm{mg} / \mathrm{kg}(\mathrm{B} 3)$ and $40 \mathrm{mg} / \mathrm{kg}(\mathrm{B} 4)(P>0.05)$, there was a significant deviation between the rest combination $(P<0.05)$. So the better combination of medication time and therapeutic dose is $\mathrm{A} 1 \mathrm{~B} 3$ or $\mathrm{A} 1 \mathrm{~B} 4$ or $\mathrm{A} 2 \mathrm{~B} 3$ or $\mathrm{A} 2 \mathrm{~B} 4$. Considering the minimization of medication dose and maximization of therapeutic time, it is presumed that $\mathrm{A} 2 \mathrm{~B} 3$ is the best combination, namely the best therapeutic time window and the best therapeutic dose of picroside II is ischemia $1.5 \mathrm{~h}$ with $20 \mathrm{mg} / \mathrm{kg}$ body.

Table 6. The expression positive cells of S-100.

\begin{tabular}{ccccc}
\hline Drug Dose & Ischemia 1.0 h & Ischemia 1.5 h & Ischemia 2.0 h & Ischemia 2.5 h \\
\hline $5 \mathrm{mg} / \mathrm{kg}$ & 43.88 & 45.00 & 45.90 & 46.00 \\
$10 \mathrm{mg} / \mathrm{kg}$ & 40.90 & 44.50 & 45.10 & 45.70 \\
$20 \mathrm{mg} / \mathrm{kg}$ & 37.06 & 38.25 & 40.00 & 44.60 \\
$40 \mathrm{mg} / \mathrm{kg}$ & 36.03 & 37.60 & 39.00 & 44.00 \\
\hline
\end{tabular}

Table 7. ANOVA of positive cells of S-100.

\begin{tabular}{cccccc}
\hline Variation source & SS & df & MS & $\boldsymbol{F}$ & $\boldsymbol{P}$ \\
\hline Time & 66.09 & 3 & 22.03 & 11.36 & 0.01 \\
Dose & 106.18 & 3 & 35.39 & 18.26 & 0.01 \\
Time*Dose & 7.69 & 3 & 2.56 & 1.32 & 0.35 \\
\hline Error & 19.00 & 6 & 1.94 & & \\
\hline
\end{tabular}

The significant probability of independent variable time was $P=0.01<0.05$; the significant probability of independent variable dose was $P=0.01<0.05$; the significant probability of independent variable interaction was $P=0.35>0.05$.

\subsection{Discussion}

Orthogonal layout can balance sampling in the changing range of variable factors, and can enhance the representation of each test with minimum animal number and test times. Orthogonal layout has characteristics of balanced scattering, which satisfies some prerequisites of a comprehensive test, shortened test cycle and elevated test efficiency to achieve a better test aim. In this paper, the authors applied orthogonal layout to design roundly, compared synthetically with statistical analysis to obtain a 
better therapeutic schedule to get the best treatment effectiveness with a small number of tests. For statistical analysis of the orthogonal test, we chose 2-way ANOVA.

In this experiment, the neurological behavioral function was evaluated by Bendeson's test to judge the therapeutic effect of picroside II on cerebral ischemic injury, TTC staining was observed and calculate the cerebral infarction volume to indicate the severity of cerebral ischemic injury. The neuroglial mark-protein S-100 [24-26] and the neuron-specific enolase (NSE) are sensitive indexes to evaluate cerebral ischemic injury [27,28]. NSE is a kind of acidic soluble protein only existing in nervous tissue. According to their three subunits with different immunity, enolases are divided into five kinds of isozymes as follows: type $\alpha \alpha, \beta \beta, \gamma \gamma, \alpha \beta$ and $\alpha \gamma$, of which type $\gamma \gamma$ exists specially in nerve cells and being named as NSE. Enolases participate in the metabolism of glucolysis, catalysis $\alpha$-phosphoglyceric acid into enolphosphopyruvate. S-100 protein is an acidity calcium-binding protein, not simple protein but boodle of micromolecule protein with $\alpha$ and $\beta$ subunits, of which the S-100 with $\beta$-subunit particularly exist in nerve tissue, and mainly in gliacyte. S-100 is a kind of intercellular calcium-receptor protein and regulates energy metabolism, promotes axon growth and gliocyte proliferation, stabilizes internal environment of calcium ion, etc. In the physiological circumstances, the contents of NSE and S-100 in brain tissue and serum are seldom and increase after brain ischemic injury to release in to the blood circulation because of cerebral ischemia injuring the blood-brain barrier. NSE and S-100 are neurochemistry markers reflecting the severity of brain tissue damage [25], so it could reflect the neuroprotective effects of picroside II on cerebral ischemia by detecting the contents of NSE and S-100 in brain tissue and serum.

In this experiment, the authors designed four time points at $1 \mathrm{~h}, 1.5 \mathrm{~h}, 2 \mathrm{~h}$ and $2.5 \mathrm{~h}$ after brain ischemic injury, and inject intraperitoneally picroside II with four therapeutic doses of $5 \mathrm{mg} / \mathrm{kg}$, $10 \mathrm{mg} / \mathrm{kg}, 20 \mathrm{mg} / \mathrm{kg}$ and $40 \mathrm{mg} / \mathrm{kg}$. The experiment was carried out according to orthogonal table of $\left[L_{16}\left(4^{5}\right)\right]$ to explore the best therapeutic dose and best time window of picroside II in treating cerebral ischemic injury by neurological faction scale, TTC staining to measure cerebral infarction volume and the expressions of NSE and S-100, etc. The results indicated that there is a significant difference between administering drug time and therapeutic drug dose of picroside II in influencing the multiple comparison of statistical analysis showed that the best combination is not with accordant by different indexes. Considering minimization of medication dose and maximization of therapeutic time window, it is suggested the best choose of A1B3 composition, or the best therapeutic time window is at $1.0 \mathrm{~h}$ after ischemia and the best therapeutic dose of picroside II is $20 \mathrm{mg} / \mathrm{kg}$. Because the mechanism of cerebral ischemic injury is very complicated and only four indexes was observed in this experiment, the results could not possibly all be right. So the effect and mechanism of picroside II and the golden evaluating indexes need to be further studied in further experiments.

\section{Experimental Section}

\subsection{Animal Model of MCAO}

Adult healthy male Wistar rat, SPF grade, weight 240-260 g, were supplied by the Experiment Animal Center of Qingdao Drug Inspection Institute (SCXK (LU) 20090100). The local legislation for ethics of experiment on animals and guidelines for the care and use of laboratory animals were 
followed in all animal procedures. This experiment was approved by the Ethics Committee of Qingdao University Medical College (No. QUMC 2011-09). All animals were acclimatized for 7 days and allowed free access to food and water in a room temperature $\left(23 \pm 2{ }^{\circ} \mathrm{C}\right)$ and humidity-controlled housing with natural illumination and absolute diet at preoperative $12 \mathrm{~h}$ before operation. The rats were anesthetized by injecting intraperitoneally $100 \mathrm{~g} / \mathrm{L}$ chloral hydrate $(300 \mathrm{mg} / \mathrm{kg})$ and fixed in supine position to conduct aseptic operation. The middle cerebral artery occlusion (MCAO) model was established by inserting intraluminaly a monofilament suture from the left external-internal carotid artery (ECA-ICA) into the middle cerebral artery (MCA) for cerebral ischemia [29]. Core body temperature was checked by a rectal probe and maintained at $36-37^{\circ} \mathrm{C}$ using a homeothermic blanket control unit (Qingdao Apparatus, China) during and after the surgery operation. The successful model rats showed left Horner's sign, right forelimb flexing and circling rightward as running.

\subsection{Orthogonal Experimental Design}

Sixteen successful MCAO rat models were internalized into the experiment and divided randomly according to the principle of orthogonal experimental design of $\left[L_{16}\left(4^{5}\right)\right]$ consisting of two impact factors with four impact levels (Table 8). The impact factor $\mathrm{A}$ is the therapeutic time widow designed four levels: $1.0 \mathrm{~h}, 1.5 \mathrm{~h}, 2.0 \mathrm{~h}, 2.5 \mathrm{~h}$ after ischemia. The impact factor B is the therapeutic drug dose which has four levels as follows: $5 \mathrm{mg} / \mathrm{kg}, 10 \mathrm{mg} / \mathrm{kg}, 20 \mathrm{mg} / \mathrm{kg}$ and $40 \mathrm{mg} / \mathrm{kg}$ body weight (Table 5).

Table 8. Orthogonal experimental design of $\left[L_{16}\left(4^{5}\right)\right]$.

\begin{tabular}{|c|c|c|c|c|c|}
\hline Therapeutic dose & $\begin{array}{l}\text { Ischemia } \\
1.0 \text { h (A1) }\end{array}$ & $\begin{array}{l}\text { Ischemia } \\
1.5 \text { h (A2) }\end{array}$ & $\begin{array}{l}\text { Ischemia } \\
2.0 \text { h (A3) }\end{array}$ & $\begin{array}{l}\text { Ischemia } \\
2.5 \text { h (A4) }\end{array}$ & $\begin{array}{c}\text { Therapeutic } \\
\text { dose }\end{array}$ \\
\hline $5 \mathrm{mg} / \mathrm{kg}(\mathrm{B} 1)$ & $1.0 \times 5$ & $1.5 \times 5$ & $2.0 \times 5$ & $2.5 \times 5$ & $5 \mathrm{mg} / \mathrm{kg}(\mathrm{B} 1)$ \\
\hline $10 \mathrm{mg} / \mathrm{kg}(\mathrm{B} 2)$ & $1.0 \times 10$ & $1.5 \times 10$ & $2.0 \times 10$ & $2.5 \times 10$ & $10 \mathrm{mg} / \mathrm{kg}$ (B2) \\
\hline $20 \mathrm{mg} / \mathrm{kg}(\mathrm{B} 3)$ & $1.0 \times 20$ & $1.5 \times 20$ & $2.0 \times 20$ & $2.5 \times 20$ & $20 \mathrm{mg} / \mathrm{kg}$ (B3) \\
\hline $40 \mathrm{mg} / \mathrm{kg}(\mathrm{B} 4)$ & $1.0 \times 40$ & $1.5 \times 40$ & $2.0 \times 40$ & $2.5 \times 40$ & $40 \mathrm{mg} / \mathrm{kg}$ (B4) \\
\hline
\end{tabular}

\subsection{Treatment Methods}

Picroside II (Tianjin Kuiqing Medical Technology Co., Ltd., CAS No: 39012-20-9, purity >98\%) was diluted into $1 \%$ solution with $0.1 \mathrm{~mol} / \mathrm{L}$ PBS and injected intraperitoneally according to the corresponding designed doses in the orthogonal layout $\left[L_{16}\left(4^{5}\right)\right]$. After treatment for $24 \mathrm{~h}$, the rats were killed to detect the corresponding indexes.

\subsection{Observation Indexes}

\subsubsection{Neurological Defect Test}

After treatment with picroside II, the neurological behavioral function scales were performed by Bederson's test [30] in each rats. The higher the score, the more severe the neurological function defect. Score 0: no behavioral deficiency; Score 1: forelimb buckling (the tail lifting-suspension test positive); Score 2: lateral thrust resistance decreased (lateral thrust test positive) and forelimb buckling, no circling; Score 3: the same as midrange behavior and circling spontaneously. 


\subsubsection{The Cerebral Infarction Volume}

After treatment with picroside II, all rats were anesthetized with $100 \mathrm{~g} / \mathrm{L}$ chloral hydrate $(300 \mathrm{mg} / \mathrm{kg})$ and then the brain was take out completely to be cut five coronal sections of $2 \mathrm{~mm}$ thickness backward from the Bregma. Five coronal sections were put into $20 \mathrm{~g} / \mathrm{L}$ TTC phosphate buffer at $37^{\circ} \mathrm{C}$ and then fixed in $40 \mathrm{~g} / \mathrm{L}$ poly-formaldehyde. The normal brain tissues showed red and infarct tissue is white (Figure 1). The infarct volume is determined by Adobe PhotoShop CS after taking a photograph, and expressed as the percentage of the brain infarct size and homonymy brain hemisphere (\%).

Figure 1. The cerebral infarction volume. The normal brain tissues showed red and infarct tissue white by TTC staining.

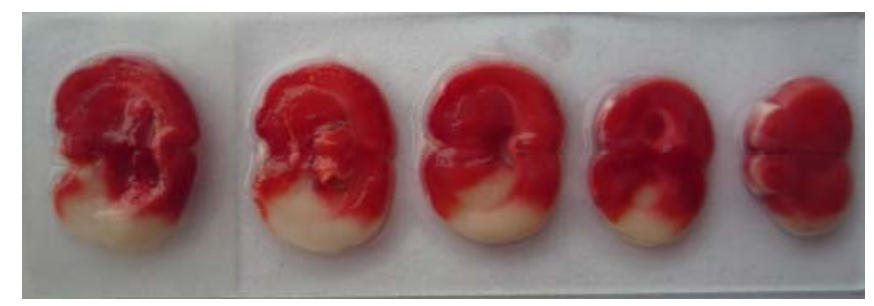

\subsubsection{Immunohistochemisty}

After treatment with picroside II, total of rats were anesthetized with $100 \mathrm{~g} / \mathrm{L}$ chloral hydrate $(300 \mathrm{mg} / \mathrm{kg}$ ) and fixed with $40 \mathrm{~g} / \mathrm{L}$ poly-formaldehyde from cardiac perfusion to take out the brain completely. The brain was dehydrated by gradient ethanol, cleared by xylene, embedded in paraffin and sliced backward from optic chiasma into pieces of thickness $5 \mu \mathrm{m}$. Then adhered those slices to the sections prepared with poly-L-lysine, and finally stored at $4{ }^{\circ} \mathrm{C}$. Rabbit anti-rat NSE and S-100 moloclonal antibodies, SABC immunohistochemisty kit and DAB chromogenic liquor were provided by Boster Biological Company, Wuhan, China. The paraffin section were deparaffinized according to directions, then colored by DAB and observed under light microscope to count the positive cells with brown granules in cytoplasm. And the slides with the addition of $0.01 \mathrm{mmol} / \mathrm{L}$ PBS (containing 1:200 non-immunity animal serum), instead of primary antibody, showed no response. Five serial section ( $1 \mathrm{~mm}$ backward from optic chiasma) of each rat were randomly chosen and observed five visual fields of cortical area under light microscope (400 times) to count the number of positive cells of every visual fields and expressed as mean \pm standard error $(\bar{x} \pm \mathrm{s})$ (Figure 2).

Figure 2. The expressions of NSE in cortex (A) and S-100 in hippocampus (B). The immunochemical positive cells showed brown granules in cytoplasm, bar $25 \mu \mathrm{m}$.
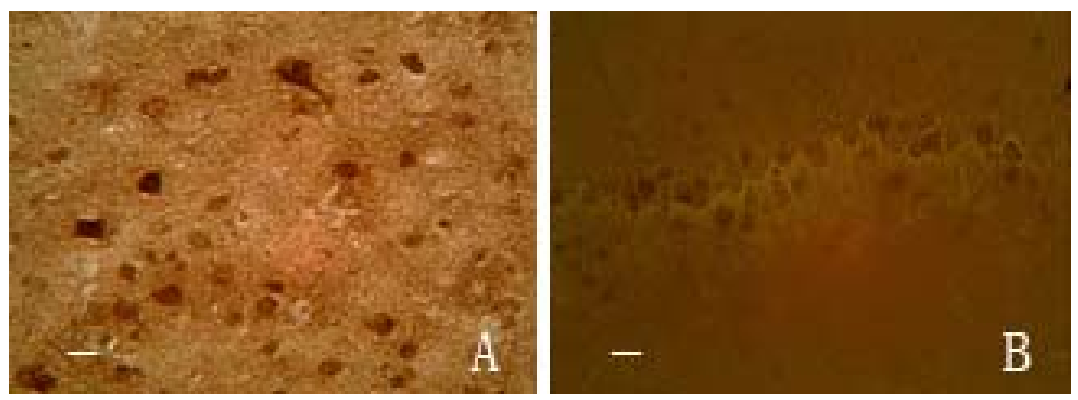


\subsection{Statistical Analysis}

SPSS 17.0 software was used for data statistical analysis (Table 9). According to the result, multi-group comparison was made by analysis of orthogonal test whether different level of administrating time and therapeutic dose had significant deviation or not, and whether their interaction on each detected index had significant deviation or not, meanwhile to explore the best therapeutic drug dose and the therapeutic time window. Values were considered to be significant when $P$ was less than 0.05 .

Table 9. $\left[L_{16}\left(4^{5}\right)\right]$ orthogonal layout and the results of infarction volume.

\begin{tabular}{ccccccc}
\hline \multirow{2}{*}{ Test NO. } & \multicolumn{7}{c}{ Rank NO. } & Infarction \\
\cline { 2 - 6 } & A & B & C & D & E & 69.05 \\
\hline 1 & 1 & 1 & 1 & 1 & 1 & 66.20 \\
2 & 1 & 2 & 2 & 2 & 2 & 64.90 \\
3 & 1 & 3 & 3 & 3 & 3 & 64.50 \\
4 & 1 & 4 & 4 & 4 & 4 & 73.00 \\
5 & 2 & 1 & 2 & 3 & 4 & 71.50 \\
6 & 2 & 2 & 1 & 4 & 3 & 69.30 \\
7 & 2 & 3 & 4 & 1 & 2 & 68.90 \\
8 & 2 & 4 & 3 & 2 & 1 & 73.40 \\
9 & 3 & 1 & 3 & 4 & 2 & 72.10 \\
10 & 3 & 2 & 4 & 3 & 1 & 71.60 \\
11 & 3 & 3 & 1 & 2 & 4 & 70.80 \\
12 & 3 & 4 & 2 & 1 & 3 & 75.50 \\
13 & 4 & 1 & 4 & 2 & 3 & 73.90 \\
14 & 4 & 2 & 3 & 1 & 4 & 72.00 \\
15 & 4 & 3 & 2 & 4 & 1 & \\
16 & 4 & 4 & 1 & 3 & 2 & \\
\hline I & 264.65 & 290.95 & 284.15 & & & \\
II & 282.70 & 284.10 & 283.90 & & & \\
III & 287.90 & 279.70 & 281.50 & & & \\
IV & 295.70 & 276.20 & 281.40 & & & \\
SS & 130.46 & 30.32 & 1.677 & & & \\
\hline
\end{tabular}

\section{Conclusions}

This study suggested the optimal composition of the therapeutic dose and time window of picroside II in treating cerebral ischemic injury should be injecting picroside II intraperitoneally with $20 \mathrm{mg} / \mathrm{kg}$ body weight at ischemia $1.5 \mathrm{~h}$ after considering the minimization of medication dose and maximization of therapeutic time.

\section{Acknowledgements}

This study was supported by grant-in-aids for The National Natural Science Foundation of China (grant No. 30873391 and No. 81041092) and The Natural Science Foundation of Shandong Province (ZR2011HM050). 


\section{References}

1. Manneville, S.E.; Manneville, J.B.; Adamson, P.; Wilbourn, B.; Greenwood, J.; Couraud, P.O. ICAM-1-coupled cytosskeletal tearrangements and transcendothelial lymphocyte migration involve intracellular calcium signaling in brain endothelial cell lines. J. Immunol. 2000, 165, 3375-3383.

2. Caso, J.R.; Pradillo, J.M.; Hurtado, O.; Leza, J.C.; Moro, M.A.; Lizasoain, I. Toll-like receptor 4 is involved in subacute stress- induced neuroinflammation and in the worsening of experimental stroke. Stroke 2008, 39, 1314-1320.

3. Bi, X.; Yan, B.; Fang, S.; He, J.; Li, X.M.; Kong, J. Quetiapine regulates neurogenesis in ischemic mice by inhibiting NF-kappa B p65/p50 expression. Neurol. Res. 2009, 31, 159-166.

4. Kruijk, J.R.; Leffers, P.; Menheere, P.P.; Meerhoff, S.; Twijnstra, A. S-100 $\beta$ and neuron-specific enolase in serum of mild traumatic brain injury patients. A comparison with health controls. Acta Neurol. Scand. 2001, 103, 175-179.

5. Basile, A.M.; Fusi, C.; Conti, A.A.; Pracucci, G.; DiCarlo, A.; Noferi, D.; Carbonetto, F.; Pretelli, P.; Calamai, G.; Vaccari, M.; et al. S-100 protein and neuron-specific enolase as markers of subclinical cerebral damage after cardiac surgery: preliminary observation of a 6-month follow-up study. Eur. Neurol. 2001, 45, 151-159.

6. Kessler, F.H.; Woody, G.; Portela, L.V.; Tort, A.B.; DeBoni, R.; Peuker, A.C.; Genro, V.; von Diemen, L.; de Souza, D.O.; Pechansky, F. Brain injury markers (s100ß and NSE) in chronic cocaine dependents. Rev. Bras. Psiquiatr. 2007, 29, 134-139.

7. Li, P.; Matsunaga, K.; Yamakuni, T.; Ohizumi, Y. Potentiation of nerve growth factor-action by picrosides I and II, natural iridoids, in PC12D cells. Eur. J. Pharmacol. 2000, 406, 203-208.

8. Li, P.; Matsunaga, K.; Yamakuni, T.; Ohizumi, Y. Picrosides I and II, selective enhancers of the mitogen-activated protein kinase-dependent signaling pathway in the action of neuritogenic substances on PC12D cells. Life Sci. 2002, 71, 1821-1835.

9. Tao, Y.W.; Liu, J.W.; Wei, D.Z.; Su, W.; Zhou, W.Y. Protective effect of Picroside II on the damage of PC12 cells in vitro. Chin. J. Clin. Pharmacol. Ther. 2003, 8, 27-30.

10. Guo, M.C.; Cao, Y.; Liu, J.W. Protective effects of picroside II on glutamate injury of PC12 cells. Chin. J. Clin. Pharmacol. Ther. 2007, 12, 440-443.

11. Li, T.; Liu, J.W.; Zhang, X.D.; Guo, M.C.; Ji, G. The neuroprotective effect of picroside II from hu-huang-lian against oxidative stress. Am. J. Chin. Med. 2007, 35, 681-691.

12. Liu, J.W.; Yu, Y.J.; Zheng, P.Y.; Zhang, X.D.; Li, T.; Cao, Y.; Guo, M.C. Synergistic protective effect of picroside II and NGF on PC12 cells against oxidative stress induced by $\mathrm{H}_{2} \mathrm{O}_{2}$. Pharmacol. Rep. 2007, 59, 573-579.

13. Yan, W.J.; Li, Z.; Wang, H.P.; Shen, W.; Du, F. Picroside II inhibit apoptosis and expressions of iNOS following cerebral ischemic reperfusion injury in rats. Chin. Pharmacol. Bull. 2009, 25, 1677-1678.

14. Yang, X.W.; Ji, X.M.; Guo, Y.L.; Du, F. Effect of rhizoma picrorhizae on nerve growth factor in rat brain following cerebral ischemia. Acta Acad. Med. Qingdao Univ. 2008, 44, 69-71. 
15. Li, Z.; Li, Q.; Guo, Y.L.; Qin, L.H.; Luan, L.J. The interference effect of picroside II on cerebral ischemia reperfusion injury in rats. Acta Anat. Sinica 2010, 41, 9-12.

16. Guo, Y.L.; Xu, X.Y.; Li, Q.; Li, Z.; Du, F. Anti-inflammation effects of Picroside II in cerebral ischemic injury rats. Behav. Brain Funct. 2010, 6, 43-53.

17. Li, Q.; Li, Z.; Xu, X.Y.; Guo, Y.L.; Du, F. Neuroprotective properties of picroside II in rat model of focal cerebral ischemia. Int. J. Mol. Sci. 2010, 11, 4580-4590.

18. Li, Z.; Xu, X.Y.; Li, Q.; Zhang, M.Z.; Shen, W. Protective mechanisms of picroside II on aquaporin-4 expression in a rat model of cerebral ischemia/reperfusion injury. Neural Regen. Res. 2010, 5, 411-417.

19. Li, X.; Xu, X.Y.; Li, Z.; Guo, Y.L.; Li, Q.; Li, X.D.; Zhou, Z. Picroside II down-regulates matrix metalloproteinase-9 expression following cerebral ischemia/reperfusion injury in rats. Neural Regen. Res. 2010, 5, 1403-1407.

20. Li, Z.; Xu, X.Y.; Shen, W.; Guo, Y.L. The interferring effects of picroside II on the expressions of $\mathrm{NF}-\kappa \mathrm{B}$ and $\mathrm{I}-\kappa \mathrm{B}$ following cerebral ischemia reperfusion injury in rats. Chin. Pharmacol. Bull. 2010, 26, 52-56.

21. Guo, Y.L.; Shen, W.; Du, F.; Li, Q.; Li, Z. Effect of Picroside II on Expressions of TLR4 and $\mathrm{NF \kappa B}$ in Rats with Cerebral Ischemia Reperfusion Injury (in Chinese). Chin. J. Integr. Trad. West. Med. 2011, 31, 58-61.

22. Li, Q.; Guo, Y.L.; Li, Z.; Xu, X.Y. The interference of picroside II on the expressions of Caspase-3 and PARP following cerebral ischemia reperfusion injury in rats. Chin. Pharmacol. Bull. 2010, 26, 342-345.

23. Sun, L.; Li, X.D.; Wang, L.; Qin, L.H.; Guo, Y.L.; Zhou, Z. The Anti-oxidant effect and the possible mechanism of picroside II in cerebral ischemia reperfusion injury in rats. Neural Regen. Res. 2011, 6, 1141-1146.

24. Butterworth, R.J.; Wassif, W.S.; Sherwood, R.A.; Gerges, A.; Poyser, K.H; Garthwaite, J.; Peters, T.J.; Bath, P.M. Serum neuron-specific enolase, carnosinase, and their ratio in acute stroke. Stroke 1996, 27, 2064-2068.

25. Abra, H.D.; Butterworth, R.J.; Bath, P.M.; Wassif, W.S.; Garthwaite, J.; Sherwood, R.A. Serum S-100 protein relationship to clinical outcome in acute stroke. Ann. Clin. Biochem. 1997, 34, 366-370.

26. Naeimi, Z.S.; Weinhofer, A.; Sarahrudi, K. Predictive value of S-100 $\beta$ protein and neuron specific-enolase as markers of traumaticbrain damage in clinical use. Brain Injury 2006, 20, 463-468.

27. Jin, L.Y.; Liu, Z.Y.; Yang, X.W.; Guo, Y.L. The expression and serum level of NSE and S-100 $\beta$ after cerebral ischemia reperfusion in rabbits. Chin. J. Rehab. Med. 2007, 22, 964-967.

28. Niu, T.X.; Shi, Z.Y.; Luo, J.J.; Meng, X.D. Determination and Clinical Significance of NSE and S-100ß Protein in Hypoxia-ischemia Brain Injured Rats (in Chinese). Chin. J. Comp. Med. 2009, 19, 34-37.

29. Longa, E.Z.; Weinstein, P.R.; Carlson, S.; Cummins, R. Reversible middle cerebral artery occlusion without craniectomy in rats. Stroke 1989, 20, 84-91. 
30. Bederson, J.B.; Pitts, L.H.; Tsuji, M.; Nishimura, M.C.; Davis, R.L.; Bartkowski, H. Rat middle cerebral artery occlusion: Evaluation of the model and development of a neurologic examination. Stroke 1986, 17, 472-476.

(C) 2012 by the authors; licensee MDPI, Basel, Switzerland. This article is an open access article distributed under the terms and conditions of the Creative Commons Attribution license (http://creativecommons.org/licenses/by/3.0/) 